
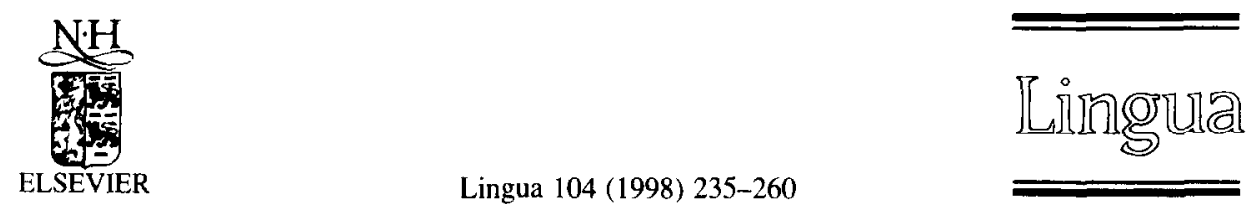

Lingua 104 (1998) 235-260

\title{
The semantic status of discourse markers ${ }^{\text {ts }}$
}

\author{
Maj-Britt Mosegaard Hansen* \\ Department of Romance Languages, University of Copenhagen, \\ Njalsgade 80. 2300 Copenhagen S. Denmark
}

Received 6 March 1997; revised version 5 January 1998

\begin{abstract}
In this paper, I propose a definition of discourse markers, incorporating a discussion of their status within linguistics in general, and more specifically their semantic status. With respect to the latter, I consider at some length what type of semantic theory is needed to account for the meanings and functions of markers. Subsequently, I give a brief overview of some of the more important previous research on markers, and I end by presenting an equally brief exemplary analysis of one specific French discourse marker, namcly bon.
\end{abstract}

\section{Introduction}

The systematic study of discourse markers, such as the underlined items in (1)-(4) ${ }^{1}$ is a fairly recent development within the field of linguistics, and the precise nature of these items is still a matter of debate.

(1) ... et il me semble que c'est dans celui-ci/ elle nous a/ sur de:s des colonnes, y a vraiment, des cartouches, alors assez profonds avec des dessins, répétitifs, alors je sais plus si c'est le crocodile, ou,, ouais avec des têtes et vraiment pour l'instant c'est une énigme ... (VE: 54)

\footnotetext{
I I would like to thank Peter Harder, Henning Nølke, and one anonymous Lingua referee in particular for their extremely useful comments on earlier versions of this text. Needless to say, they are not responsible for its present form or contents.

* E-mail: maj@coco.ihi.ku.dk

I am grateful to Professor Mary-Annick Morel of the UFR de linguistique française at the Université de Paris III for allowing me access to their corpora.

The following transcription conventions should be noted: , and ,, indicate short and somewhat longer pauses in the speech-stream; / indicates an abrupt break in the speech-stream; \& and \&\& indicate the beginning and end of overlap (where two or more instances of overlap follow each other, $\S$ and $\S \S$ are also used to distinguish them); ? indicates rising intonation; CAPITALS indicate intonational emphasis: $\therefore . .{ }^{\circ}$ indicates low pitch; and underlining indicates the item commented on in the main text.
} 
(2) A. il est tout petit il est $\&$ il est

B. \& je vois pas bon c'est pas grave $(\mathrm{CV}: 6)$

(3) A. mm remarque c'était avec toi qu'ils étaient passés à Carnac et puis ils en ont fait soixante dix

B. ah ouais ouais ouais

A. et tu sais ben tiens je t'ai pas raconté le dernier jour ah mais faut que je te raconte ça (CV: 16)

(4) ... après y en avait un autre après alors si tu veux c'était ça c'était que en fait on prenait l'histoire comme si ça se passait maintenant dans dans la colo en question ... (CV: 9)

In this paper, I will begin by proposing a definition of discourse markers, incorporating a discussion of their status within linguistics in general, and more specifically their semantic status. With respect to the latter, I will consider at some length what type of semantic theory is needed to account for the meanings and functions of markers. Subsequently, I will give a bricf overvicw of some of the more important previous research on markers, and I will end by presenting an equally brief analysis of one specific French discourse marker, namely bon.

\section{What are discourse markers?}

I define markers as linguistic items which fulfil a non-propositional, metadiscursive (primarily connective) function, and whose scope is inherently variable, such that it may comprise both sub-sentential and supra-sentential units. ${ }^{2}$ I will argue that, semantically, markers are best seen as processing instructions intended to aid the hearer in integrating the unit hosting the marker into a coherent mental representation of the unfolding discourse.

It is fairly clear that the category of discourse markers cannot be described in morpho-syntactic terms, but is rather of a functional-pragmatic nature (cf. Lamiroy and Swiggers, 1991: 123). Items which may be used as markers may originate in quite different distributional classes, where they often have formally identical counterparts that are not used as markers, and which do contribute to the propositional content of the utterances in which they appear. Examples (5)-(8) illustrate this difference:

(5) Il avait attendu l'arrivée du marin, qui commandait alors le Saturnia (E. Peisson)

(6) Ce repas était très bon

(7) Tiens ça un instant, t'es gentil!

(8) Si tu veux, je t'emmène à la soirée avec moi

2 In Hansen (1998: Ch. 6), however, I argue that the lower bound of the scope of a discourse marker is constituted by the so-called 'discourse act' (Roulet, 1991: 65). 
Whereas (1)-(4) exemplify discourse-marking uses of the underlined items, (5)-(8) illustrate their non-discourse-marking uses.

Items and constructions which are capable of taking on a discourse marking function may indicate the specific nature of that function more or less explicitly. Thus, there is a cline of semantic transparency from comme je l'ai souligné tout à l'heure or en guise de conclusion, through si tu veux or dites, to enfin or ben. There appears, in general, to be a correlation between the degree of semantic transparency of markers, and the extent to which they may be said to be grammaticalized, such that, on the whole, multi-word constructions tend to be both compositional and productive, whereas the more particle-like items tend to be rather opaque in meaning and are often phonologically reduced as compared to their non-discourse-marking counterparts, and the inventory of such particles in a given language appears to be relatively fixed.

As far as the more compositional items are concerned, the difference between their discourse marking use and their truth-conditional use seems to a large extent to be due to a simple expansion of structural scope (cf. Traugott, 1997). There is a quite straightforward semantic relation between the two uses of in other words in (9) and $\left(9^{\prime}\right)::^{3}$

(9) She asked him to rewrite it in other words

(9') In other words, you must rewrite the whole essay

the essential difference being that, in (9), the expression functions VP-internally, as a manner adverbial, while, in $\left(9^{\prime}\right)$, it has scope over the entire speech act and is not part of the propositional content of that speech act.

In contrast, an item like anyway not only has three different scope possibilities in present-day English, viz. - according to Traugott (1997) - VP, IP, and E(xpression phrase) [i.e. what I would call the speech act]:

(10) She did it (in) any (old) way she pleased

(11) In one instance a resterilizing service returned a pacemaker to Walton labeled 'Not For Human Implant', but he sold it anyway and it was implanted in a patient (23 June 1992 UPI)

(12) So uhm - anyway just think about this offer (London Lund Corpus, line 4,200) [all examples from Traugott, 1997]

but its meaning changes from that of a manner adverbial in (10), to (non-truth-conditionally) indicating concession in (11), and finally to marking the resumption of a topic after a digression in (12).

Now, it would seem that, although linguistic elements typically start out having a propositional function, and only achieve discourse marking functions over time (cf. Traugott, 1990: 499), discourse markers cannot inherently be end points of gram-

The examples are due to an anonymous referee. 
maticalization: although some markers may be syntactically integrated, they equally often seem to be extra-clausal, and positionally variable, elements which make no predictions about, nor are they predicted by, the presence of other syntactic elements in their host units. Their function is typically adverbial or interjective, and as such they may be deleted from their host units without this resulting in ungrammaticality. ${ }^{4}$ So, it is probably the case that discourse markers are typically items that are still in the process of being grammaticalized, and which are therefore naturally located at various points towards the middle of a grammaticalization cline going from content words at one end to pure function words at the other. This would account for the heterogeneous nature of the category, largely compositional markers like in other words being closer to the content pole, and largely opaque ones like well being closer to the grammatical end of the cline.

\section{The multifunctionality of discourse markers}

Now, it has frequently been observed that discourse markers tend to be multifunctional. Furthermore, the farther they have moved along the grammaticalization cline, the greater variety of function they seem capable of assuming. Thus, to the naked eye, examples such as (13)-(15) may not seem to have much in common, which is no doubt one reason for the traditional tendency to consider the less semantically transparent markers as 'fillers', i.e. contentless hesitation markers, or the like:

(13) A. est-ce que:

B. alors attendez si vous permettez René/ si vous permettez Henri Amouroux euh: j'aimerais que Claude Estier d'abord réponde et ensuite vous interviendrez

A. bon, d'accord, très bien (VS1: 4)

(14) A. mais est-ce qu'i: il y a aucun contact?

B. no:n si tu veu:x

A. remarque si il rentre à une heure du matin vous risquez pas de communiquer hein

B. mais de toute façon on cherche pas à: communiquer avec lui, (h) mai:s on cherche pas à communiqu/ bon y a une communication, mais on cherche pas à: communiquer profondément avec lui (CT: 18)

4 I do, however, include conjunctions used on what Sweetser (1990) calls the epistemic level and the speech act level, as opposed to the propositional (or 'content') level, in my definition of markers. Cf. the following examples:

(i) John married Sue because she was rich (content-level conjunction, not a discourse marker)

(ii) Cecily couldn't have killed Algernon, because she was out of town on the night it happened (epistemic-level conjunction, discourse marker)

(iii) Have you got a minute? - Because there's something I wanted to discuss with you (speech act conjunction, discourse marker). 
(15) ... alors apparemment bon c'est peut-être vrai elle avait peut-être raison quand même ... (VE: 44)

One of the theoretical challenges posed by markers, then, is how best to account for the relationship between their various uses. Currently, three different approaches to variable meaning can be found in the literature: the homonymy, or maximalist, approach; the monosemy, or minimalist, approach; and, finally, the polysemy approach. The choice between these approaches is of course not specific to research on non-truthconditional items like discourse markers, but is one that has to be made by any scholar interested in describing the meaning of words or constructions, and I will therefore feel free to use examples from various parts of speech to support my argument.

The simplest and most traditional solution is to use the maximalist approach. Strict maximalism will attribute meaning variations such as those in (13)-(15) to the semantics of the individual item, and will specify a sometimes very large number of senses directly in the lexicon. Meaning maximalism is thus essentially of a radically semantic nature.

At the other extreme, a strict minimalist will attempt to isolate a unitary 'core' meaning, usually of a highly abstract and schematic nature, from which all uses of a given item can be derived. Any observable variations in the meaning and use of a given word or construction will then be attributed to its interaction with context. Mcaning minimalism is, in other words, a radically pragmatic approach, in which the semantics has very little work to do.

To give a concrete example which has been, and still is, subject to much debate in the literature, the conjunction et and its equivalents in other languages can be analyzed in vastly different ways. A strict maximalist will find him/herself obliged to ascribe at least five senses to this morpheme, to cover the uses in (16)-(20):

(16) Londres est la capitale d'angleterre, et Paris est la capitale de France (= logical ' \&')

(17) Hélène s'est mariée, et elle a eu un enfant (= 'and then')

(18) Stéphane a passé la soirée à draguer toutes les filles, et Chantal ne veut plus lui parler ( $=$ 'and because of that')

(19) Refais ça, et je te casserai la gueule! ( $\approx$ 'Si tu refais ça, je te casserai la gueule')

(20) Christophe est socialiste, et il a voté pour Chirac en 1995 (= 'and yet')

In fact, as Posner (1979: 386, 1980: 188) points out, these examples do not exhaust the possibilities. Depending on one's imagination, and on how precise one wants one's interpretations to be, several additional senses might be adduced.

A minimalist, on the other hand, might want to follow Grice (1975), and essentially ascribe to et the semantics of the truth-functional connective ' $\&$ ', classifying the variations in (16)-(20) as conversational implicatures.

In the case of $e t$, there are problems for both approaches which I will not go into here (but see Cohen, 1971 ; Posner, 1979, 1980; Carston, 1993, inter alia). ${ }^{5}$ 
On a more general level, strict maximalism leaves something to be desired as far as explanatory power is concerned and is often accused of confusing the meaning of words with that of the contexts in which they occur. ${ }^{6}$ It also potentially leads to problems in actual interpretation, insofar as it is unclear how hearers go about deciding which of the competing homonyms should be activated in a given context. It might of course be argued that they do this on the basis of the meaning of the other words occurring in the utterance. However, as pointed out by Moore and Carling (1982: 187), this could result in combinatorial explosion for utterances containing more than one variable unit. Moreover, since meaning maximalism is unable to show the relations between 'homonymous' items, it cannot explain the observation (Traugott, 1990) that there are certain general tendencies in lexical change, such as the tendency for items to move from the propositional through the textual, to the expressive level of discourse.

Minimalism, on the other hand, is in many ways a more theoretically satisfying approach, and one which is entirely appropriate in many cases. Thus, a construction like in other words might reasonably be described as having one basic meaning, while being capable of functioning at different levels of the utterance (the propositional content level in (9) vs. the speech act level in $\left(9^{\prime}\right)$ ), the relevant level being determined, in a concrete utterance, by the interaction of syntactic, prosodic and contextual factors.

However, insisting on a strictly minimalist approach in all cases may, as pointed out by König (1991: 175), result in descriptions that are too abstract and general to be of significant practical value, especially, we might add, if a unitary analysis of cross-categorial items is attempted. ${ }^{7}$ Moreover, the minimalist approach is unable to explain the diachronic fact that the meanings of linguistic elements frequently evolve over time, such that new uses may be added, while certain others may fall into obsolescence. Similarly, in child language acquisition, certain uses of variable items are typically acquired before others. If the minimalist stance is correct, there is no good reason why all the potential uses of a given item should not be equally available at all stages of phylo- and ontogenetic development.

There is, however, a third alternative, namely the so-called 'polysemy' approach. Analysts who take this stance assume that words may indeed have different senses

\footnotetext{
sitional content, whereas the meaning of the latter markers is of a metadiscursive, non-propositional nature. This is clearly of importance to anyone wishing to give an adequate semantic description of et. However, as the question of minimalism vs. maximalism seems to me to concern meaning-bearing items of either kind, I don't think the observation bears significantly on my point, which is simply to contrast the two competing approaches by way of an illustration.

6 It goes without saying that languages do possess genuinely homonymous items. Clearly, it would be futile to attempt to find a semantic link, let alone a common core meaning, between the two senses of English bank ('financial institution' vs. 'river bank'), for instance. Here, I am only concerned with those cases where there is a diachronic connection between the various uses of a given linguistic item, and where most (if not all) speakers would experience the uses as related, although I do not wish to imply that either of those criteria is at all straightforward (cf. Lyons, 1977: 550-552).

7 By 'cross-categorial items' I refer to words which in different uses may have different part of speech functions, such as French bon, which may be an adjective or a discourse marker, or, for a better known example, the English preposition/verb particle/adverb over (cf. Lakoff, 1987: 416ff.).
} 
which are not merely a matter of pragmatics, but that rather than being homonymous and discrete, these various senses are related in an often non-predictable, but nevertheless motivated way, either in a chain-like fashion through family resemblances, or as extensions from a prototype. ${ }^{8}$ This obviates the minimalist need to find a single basic meaning which is common to all possible uses of a word, but at the same time allows for a certain indeterminacy of meaning which is not possible on a maximalist account, insofar as the senses instantiated in particular contexts may overlap. Thus, a maximalist description would require the analyst to specify whether the alors in (21) is resultative or whether it signals the return to a previous topic following a digression (these are two of the functions which may be fulfilled by alors on my analysis, cf. Hansen, 1997, 1998: Ch. 13), since these meanings would be assumed to be distinct, whereas a 'polysemy' account can treat both as being potentially present:

(21) Tl A. ... et il m'a jamais dit Sophie ouais bon t'as tel petit problème ça va pas trop bien tu devrais faire comme ça jamais j'ai JAMAIS rien eu

T2 B. non mais ça il le dit à \& personne \&\&

T3 A. \& non \&\& si si il il l'a dit à Didier

T4 B. pas en question animation et pas en question \& de rien du tout \&\&

T5 A. \& mais si \&\& ${ }^{\circ}$ parce que Didier me l'a répété après ${ }^{\circ}$

T6 B. ah ${ }^{\circ}$ ça m'étonnerait ${ }^{\circ}$

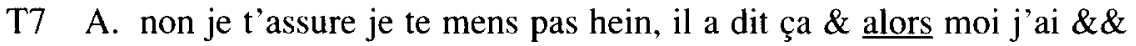

T8 B. \& ça m'étonnerait \&\&

T9 A. non non ne ne crois- \& moi vraiment

T10 B. \& parce que nous il nous a jamais aidé de cette manière-là

T11 A. alors moi j'ai jamais su que finalement j'étais, prise pour deux mois ... (CV: 25-26)

Of course, we would like to put some sort of restrictions on the number of senses to be postulated even for polysemous items. The principle followed in my work is one that is also advocated by König (1991: 175), Kroon (1995: 3.10$)^{9}$, and Foolen (1993: 64), and which the latter dubs 'methodical minimalism'. As Foolen says, this

\footnotetext{
8 One referee has expressed surprise at my using notions from prototype theory in connection with items which do not express concepts (specifically discourse markers). As a matter of fact, to do so is not at all unheard of in cognitively oriented studies where, for instance, phonemes and syntactic constructions have been described in such terms (e.g. Lakoff, 1987: 462ff.; Taylor, 1989; Winters, 1990). Although prototype theory was developed in the first instance to deal with the representation of concepts, I see no compelling reason not to allow for the possibility that certain interpretations of a given discourse marker (i.e. certain instantiations of the procedure) may be thought of as constituting the 'core' of one's representation of that marker, other uses being understood as motivated extensions from the core. On those occasions when I have asked native French speakers informally to formulate their understanding of the meaning of a specific marker, only a very few uses have been mentioned spontaneously, which seems to suggest that these are more salient than others, just as robins are more salient birds than kiwis, at least to North Americans.

9 Kroon's (1995) dissertation is unfortunately available to me only in manuscript form. The page reference therefore specifies the chapter followed by the relevant page within that chapter.
} 
is really a variant of Occam's razor which tells us, as it were, not to 'multiply senses beyond necessity', or in other words to try as far as possible to maintain the minimalist assumption of a common core meaning, while aiming for relative precision of description.

In the context of my work, that means that some apparent senses of the particles I have described in depth elsewhere are labelled as 'side effects' or implicatures of the interaction between the particles in question and the contexts in which they occur, rather than as coded features of the particles themselves. At the same time, it should be noted that frequently occurring 'side effects' may of course in time become part of the coded content of a given particle. This is a form of semantic change which is usually called 'metonymic' extension, the reality of which has been demonstrated repeatedly in grammaticalization studies (cf. Hopper and Traugott, 1993: 80ff.).

Let us return for a moment to the observation that discourse markers frequently originate in lexemes which form an integrated part of their host clause or sentence, and which do contribute to propositional content. If we look again at examples (1)-(8), we might ask the question whether we should restrict the notion of polysemy to the various senses of the discourse markers alone, and thus claim homonymy between, for instance, the discourse marker bon and the adjective bon, or whether we should perhaps try to integrate both into our semantic network, which in this case would make bon not just polysemous, but heterosemous, i.e.

"[a case] (within a single language) where two or more meanings and functions that are historically related, in the sense of deriving from the same ultimate source, are borne by reflexes of the common source element that belong in different morphosyntactic categories." (Lichtenberk, 1991: 476)

I would prefer to maintain - at least as a working hypothesis - that, in each of the pairs in examples (1)-(8), what we are dealing with are two uses of the same item, and not a pair of homonymous expressions. Importantly, therefore, when I speak of certain linguistic items as being discourse markers, it should be understood as no more than a convenient shorthand: in those frequent cases where motivated links can be postulated between the various (propositional and non-propositional) uses of an item, I find it more appropriate to speak of items which in certain contexts, and in certain syntactic positions, may fulfil a discourse marking function. This stance is of course less controversial with respect to expressions such as in other words, whose discourse marking use has not moved too far along the grammaticalization cline, than when it comes to a particle like anyway. The semantic link between the uses of anyway in (10)-(12) is, as already noted, less than fully transparent, yet the default assumption of the existence of a motivated link even in this type of case is supported by the observation that the border between propositional and non-propositional uses of some (albeit of course not all) items may in certain contexts be fuzzy:

(22) Jean a tiré. Alors, Pierre s'est écroulé

(23) Voilà ce que je te conseille. Maintenant, tu fais ce que tu veux

Alors in example (22) may with equal right be interpreted as a time adverbial or as a resultative marker. As the two readings are, moreover, not mutually exclusive, the 
speaker may well have intended that both be simultaneously available to the hearer, and, in many contexts, the utterance can be understood even if no clear choice is made between them. Similarly, in (23), it is not obvious that we have to choose between a temporal and an adversative reading of maintenant.

Such cases of propositional/non-propositional vagueness (or even merger) are not peculiar to discourse markers, but may also be found with, for instance, modal verbs, where it is not invariably clear whether a root or an epistemic meaning is intended. Indeed, the two meanings may occasionally - as in the following example - be perfectly compatible:

(24) J'ai aucune idée. Faudra qu'on demande au patron: lui, il doit savoir

The modal devoir in this example may be interpreted as meaning 'it's probable that he knows' and/or 'he has a duty to know' (cf. Coates, 1983: 78).

As Elizabeth Traugott (1990) has convincingly argued, this can be accounted for if we assume a diachronic model in which the non-propositional uses of the items in question are derived from the propositional ones through a process of increasing subjectification.

\section{Instructional semantics}

If we want to opt for polysemy in the description of discouse markers, we want of course to keep open the possibility both of synchronic inter-speaker variation and of further meaning extensions taking place in the future, and it will therefore be desirable to integrate the study of markers into a dynamic theory of semantics.

The approach I have chosen is a version of instructional semantics. The idea of seeing meanings as processing instructions does not originate with me: in fact, in recent years, a number of people have argued for an essentially, or at least partially, instructional view of linguistic semantics, among them Johnson-Laird (1977, 1983), Ducrot et al. (1980), Harder (1991, 1996), Harder and Togeby (1993), Blakemore (1987, 1992), and Nølke (1994). Instructional semantics cannot yet be said to be a unified and highly detailed framework. The relatively few writings on the subject are still largely programmatic in nature, and the various authors mentioned do not necessarily agree in detail on what a complete (future) theory should look like. Hence, what follows is my personal attempt at synthesizing the various proposals.

It must be pointed out, in this connection, that of the scholars mentioned, both Ducrot et al. (1980) and Blakemore $(1987,1992)$ specifically analyze discourse markers and other expressions of a similar nature as instructions, but that they choose to do so within a minimalist approach. In other words, the issue of how to treat meaning variation is to some extent orthogonal to the question of whether linguistic semantics should be approached in instructional terms or not. However, as I find instructional semantics to be highly compatible with polysemy, I have sought in my work to combine the two in an approach to discourse markers in particular. 
The instructional approach may be seen as an alternative to the 'container' view of linguistic meaning (cf. Moore and Carling, 1982; 150ff.). On the container view, which is more or less the traditional conception of linguistic semantics, words inherently express certain meanings which are independent of their use in concrete utterances. They thus, in a metaphorical sense, function as containers for these meanings, which in a communicative situation are simply transferred from speaker to hearer. Meanings are conceptualized as discrete entities which can be precisely and exhaustively specified, so that even in cases where a word or expression may have more than one meaning, the different senses can be clearly distinguished and listed in the lexicon. It should therefore be possible, on any given occasion of use of a particular word or expression, to relate it to one of its specified senses. It is fairly clear that, on this view, the role of the hearer is that of a mere passive recipient, who has only to 'unwrap' the ready-made meaning contained in the utterances he hears.

To understand the instructional (or in Johnson-Laird's terminology 'procedural') approach to meaning, it is useful to appeal to a distinction made in artificial intelligence between declarative and procedural knowledge: declarative (or representational) knowledge is stored explicitly, as facts or propositions, so that it can be read by a program. Procedural knowledge, on the other hand, is stored as a program of instructions for carrying out a particular task. It is not readily retrievable into consciousness by the processor, and is usually carried out more or less automatically.

Of the various proponents of instructional semantics mentioned earlier, Blakemore $(1987,1992)$ takes up the most 'conservative' stance, in as much as she maintains that some linguistic meanings are directly representational, while others are procedural. In her words,

"[t]his suggests a non-unitary theory of linguistic semantics. On the one hand there is the essentially conceptual theory that deals with the way in which elements of linguistic structure map onto concepts that is onto constituents of propositional representations that undergo computations. On the other, there is the essentially procedural theory that deals with the way in which elements of linguistic structure map directly onto computations themselves - that is, onto mental processes." (Blakemore, 1987: 144, author's emphases)

Her main examples of procedural meanings are precisely the meanings of discourse markers such as moreover, so, and after all, which it is difficult to think of as representations, and which on her analysis function as constraints both on the inferential computations their host utterances may undergo, and on the type of context to be constructed in interpreting the utterance.

Other examples of linguistic items whose meanings are fairly clearly non-declarative include the definite and indefinite articles: to borrow Heim's (1982) 'file change' metaphor, it seems more plausible to see the indefinite article in (25) as instructing the hearer to enter a new variable in his mental 'file' (i.e. his discourse model), and the definite article in (26) as instructing him to search his file cards for an already established entity which satisfies the description given, than to see them as activating the concepts 'indefiniteness' and 'definiteness', respectively: 
Other researchers, however, take a more all-encompassing view of the role of semantic instructions, whereby - rather than directly representing real-world phenomena and concepts - even content words such as nouns or verbs function in the first instance as processing instructions to the hearer. On this view, utterances do not convey meaning in and of themselves, but are rather one (no doubt privileged) means among others that a speaker can use to "cause [the hearer] to access his own 'store' of accumulated and generalized knowledge and experience, to locate what appears to make sense of the sounds he hears" (Moore and Carling, 1982: 161).

In other words, linguistic items in themselves have only a meaning potential which must be actualized by a specific hearer in a specific context, via the construction of a mental representation (cf. Harder, 1991: 131, 1996: 111). ${ }^{10}$ We might note that, as one might imagine other expressive means being used to cause hearers to access their knowledge stores, the instructional view of semantics is at least potentially able to integrate the study of linguistic meaning with the study of paralinguistic features such as intonation, and of gesture, facial expressions, proxemics, and the like.

This obviously affords the hearer a much more active role in the communicative process, which is in line with the dynamic conversation-analytic perspective that I have relied on in my analyses of French discourse particles. Conversation analysis crucially sees meanings as being continually negotiated between interlocutors on a turn-by-turn basis, such that a turn in conversation will normally display the speaker's understanding of the previous turn by her interlocutor, this understanding being subject to revision by the hearer in the following turn (cf. Heritage, 1984: 255-257). This is illustrated in (27) and $\left(27^{\prime}\right)$ :

(27) T1 A. Say, do you know how to access the World-Wide Web?

T2 B. Not now, I have to go teach a class.

T3 A. Well, I just wanted to know if you knew how.

Here, turn 2 displays B's interpretation of turn 1 as a request. This interpretation is corrected by $\mathrm{A}$ in turn 3 , which at the same time displays an understanding of turn 2 as a rejection. On the other hand, if the exchange had developed as in $\left(27^{\prime}\right)$, turn 3 would have tacitly approved B's interpretation.

$\left(27^{\prime}\right)$ Tl A. Say, do you know how to access the World-Wide Web?

T2 B. Not now, I have to go teach a class.

T3 A. Well, could you show me later maybe?

At the end of the day, it is the hearer's interpretation as much as, or even more than, the speaker's intention which determines the impact of an utterance in discourse.

\footnotetext{
10 Exactly what the role of the context is in specific instances is a problem which, to my knowledge, no theory has succeeded in solving in a manner which is truly operational, and $\mathbf{I}$ will not attempt to do so here.
} 
Where communication is successful, the two will, of course, coincide to a greater or lesser extent, but they are rarely, if ever, identical.

An important reason for seeing linguistic semantics as specifying only potential meanings is that language provides a finite means of expressing an infinite number of messages. Most, and perhaps all, linguistic units are therefore inherently variable to some degree, and the actualized meaning of a given item will be influenced by that of the other items with which it co-occurs, and by the grammatical and sequential structure imposed on them. Moreover, no two people possess exactly the same knowledge and experience, or have exactly identical mental grammars (where grammar includes knowledge of word meanings). Since hearers will necessarily bring their own knowledge and experience to bear in interpreting what they hear, 'perfect' understanding, in the form of a carbon copy in the hearer's mind of whatever thought was in the speaker's mind when she produced her utterance, is a highly unrealistic goal - if not downright unachievable. Although this is often a source of frustration to us as analysts trained to look for abstract generalizations, it is nevertheless what endows language with the flexibility necessary for the conceptualization and communication of novel experience.

If we view linguistic semantics in these terms, content words might be said to function as instructions to access particular areas of one's store of knowledge in order to set up contextually appropriate representations of states-of-affairs, while function words and syntactic constructions would be instructions on how to process what one had found there. Instead of Blakemore's (1987: 144) 'non-unitary theory of linguistic semantics', we would have a model in which abstract linguistic meanings were invariably procedural, whereas actualized utterance meanings would come in the form of mental representations, which the hearer would then be meant to integrate into a coherent mental model of the discourse as a whole.

The notion that hearers construct and continually update mental models of the discourses they hear is of course fundamentally dynamic in nature. In Hansen (1998), I combine the theory of mental models with the equally dynamic approaches embodied in the notion of polysemy, in the theory of instructional semantics, and in conversation analysis, and I argue in favor of the emergent nature of discourse structure, thereby arriving at a consistently dynamic global approach to the study of discourse markers.

In any case, if linguistic meaning is indeed instructional, and if instructions can indeed be carried out in different ways according to co- and context, then our model can fairly straightforwardly accommodate phenomena such as figurative uses of language and various forms of language change such as semantic extensions/shifts and grammaticalization.

The question of figurative uses of language is probably of lesser relevance here, but as far as diachronic change is concerned, we may assume that it originates in a few speakers' innovative uses of words or expressions in concrete situations. These innovations then gradually catch on and become conventionalized throughout the speech community. The process of conventionalization may take a long time, resulting in some measure of variation within the speech community, and during this period a 'new combination of elements' should repeatedly lead hearers who are still 
unfamiliar with the usage in question to "[assign types] of actual meaning to [...] element[s] that [were] not part of the potential meaning that existed before" (Harder and Togeby, 1993: 483). If linguistic meaning is instructional and essentially openended, rather than directly representational and circumscribed, both variation and change can be accounted for by our model. This, I find, is an interesting consequence of the instructional approach to meaning which I do not believe has been pointed out elsewhere in the literature.

The problem of course remains of how to constrain the extension of existing words and constructions to cover new areas of meaning. As Moore and Carling (1982: 186-187) note, there is little in an instructional (or, as they prefer to call it, an 'emergent') view of semantics per se which prevents linguistic units from taking on a potentially infinite variety of meanings. However, this is a problem only if you insist on seeing utterance interpretation as an exclusively cognitive phenomenon. In my view, there is no doubt that cognitive activity is essential in the analysis of meaning, but language use is also, crucially, an interactive phenomenon. Moreover, the two perspectives stand in a dialectic relationship to one another.

For one thing, the only thing that could induce an individual to attempt to interpret the words that he hears in the first place, is if he assumes the existence of some considerable measure of intersubjectivity of meanings. And the basis for such an assumption must be that he has successfully participated in communicative interaction in the past.

Secondly, the individual language user may choose, whether wilfully or by mistake, to use and interpret the words of her language in a way that differs from the norm, for instance to systematically use and interpret the word hot to mean what others refer to as cold. However, in doing so, she is likely to find herself regularly failing to reach her interactional goals, and as a result will probably be forced to adjust her semantic representation of the word accordingly. Essentially, linguistic meanings are not the property of the individual language user, but rather of the linguistic community as a whole (cf. Wittgenstein, 1971; Burge, 1989).

In other words, to allow for flexibility of meaning while at the same time securing restraint, we need to appeal to the assumption that speakers will normally wish to make themselves understood and will therefore tend not to stray too far beyond the bounds of what they assume to be shared between themselves and their interlocutors. Language use is no different from other forms of organized social activity in displaying a distinction between more or less established routines (what we might call conventions) and the particular situated behavior of individuals. Conventions in other areas of social life are likewise open to 'creative reinterpretation' by individual actors, and specifying what the conventions are, and how far they can be stretched without resulting in the breakdown of social order, is a descriptive, rather than a theoretical problem.

\subsection{A note on 'core' meanings}

Assuming that the above is true, could we not nevertheless maintain the minimalist stance, and equate the 'meaning potential' of a word or expression with some 
kind of 'core meaning', common to all uses of that word or expression, such that this core meaning is simply fleshed out by the context to yield the actualized message? The answer to this is that the isolation of such invariant core meanings has so far proved extremely difficult, if not impossible, in a very large number (perhaps the majority) of cases. ${ }^{11}$

To mention just a few examples, Harder and Togeby (1993: 478), quoting Smolensky, note that the word coffee means two slightly different things in $a$ can of coffee (= ground coffee beans) and a cup of coffee (= hot brown beverage). To these meanings we might add those in (28)-(30):

(28) They grow coffee in South America (= the fruit of a particular shrub)

(29) (In an ice cream parlor) I'd like a sugar cone with two scoops: coffee and butter pecan (= a particular flavor)

(30) We have this blouse in a variety of colors: coffee, ivory, burgundy, ... (= a particular color)

While these uses of the word coffee are clearly related, it is difficult to discern in them an invariant core of meaning which would be sufficiently precise to distinguish this noun from all others. Similarly, Moore and Carling (1982: 179, 184-185) adduce a number of possible uses of the expression to put on, such as (31)-(37):

(31) Put on the table cloth

(32) Put on your socks

(33) Put on a big smile

(34) Put on the car (= add it to the list)

(35) Put on the gas fire

(36) Put on some music

(37) Put on the potatoes ( $=$ to cook)

Again, the verb + particle combination does not mean exactly the same thing in all of these sentences, but neither are the different senses so clearly distinct as to make us want to claim homonymy (the more so since a number of additional senses could easily be added to the list). In both the coffee and the put on case, the precise meaning of these words is determined by their interaction with both the other words of the sentences in which they occur, and with the extralinguistic context.

Now, exactly the same type of problem may be found with non-content words like discourse markers. French mais, for instance, has a variety of different uses, in some cases with syntactic and distributional differences between them, such as:

11 In the case of content words, as a matter of fact, the possibility of a principled separation between a dictionary containing clearly specifiable, invariant and non-contextual knowledge of circumscribed 'literal' meanings and an encyclopedia containing pragmatic, variable and context-dependent knowledge of concepts has been cogently argued by Haiman (1980) to be untenable. 
(38) Pierre ne fume pas la cigarette, mais le cigare

(39) Il est républicain, mais honnête

(40) A. Il faut qu'on trouve quelqu'un qui sache l'espagnol

B. On pourrait contacter Ernesto. Il est espagnol

C. Non, il n'est pas espagnol, mais il est argentin

(41) Je ne sais pas quelle paire de chaussures acheter: celles-ci sont très chics, mais celles-là vont aller avec presque tous mes vêtements

(42) Je vais sortir, mais il pleut. Alors, il me faut un parapluie

(43) On ne lui donne rien à faire, mais ce qui s'appelle rien

(44) Mais il est beau, ton appartement!

(45) A. Õtez-vous de là, vieille peau, que je m'y mette!

B. Non, mais!

To my knowledge, no one has so far proposed a single unified core meaning of this connective which would succeed in accounting satisfactorily for all these uses, yet intuitively, one would not wish to describe them as any number of completely unrelated homonyms.

In view of examples such as these, I believe a model of semantics which incorporates the notions of prototypes (Rosch, 1977) and of 'family resemblances' (Wittgenstein, 1971: \$66-67), i.e. a model which gives polysemy a clear theoretical status, is to be preferred.

\section{What kind of instructions do discourse markers convey?}

Before stating my own proposal about the function of markers in greater detail, it will be useful to briefly consider a few representative earlier proposals.

The first scholar to take French particles seriously as an object of study was Elisabeth Gülich, whose (1970) dissertation introduced the term Gliederungssignale, or segmentation signals, to cover precisely the items treated in my thesis, and more. Like my work, Gülich's study is based on recorded speech of various kinds and takes into account units of language use above the sentence. Gülich sees her segmentation signals as mainly a form of oral punctuation marks, devoid of semantic content and largely interchangeable, which divide spoken discourse into smaller and more manageable units, and she distributes the items under consideration into three groups, so-called Eröffnungssignale, or opening signals, Unterbrechungssignale, or interruption signals, and Schlußsignale, or end signals.

However, although clearly ahead of its time in a number of respects, Gülich's model suffers from a number of shortcomings. For one thing, some markers fall into more than one of the three sub-categories mentioned, so that the model ceases to distinguish between items. Secondly, markers are not freely interchangeable: as a matter of fact, this notion is undermined by one of her own examples (Gülich, 1970: 144), in which the speaker introduces the narration of a past experience as in (46):

(46) Tenez: l'an dernier, j'avais rendez-vous avec un Suédois, à Luxembourg 
but is interrupted shortly thereafter, and has to resume as follows: Eh bien l'an dernier j'avais donc rendez-vous avec un Suédois

This, according to Gülich, demonstrates that tenez and eh bien have identical functions, and are mere contentless openers. Clearly, however, that is not so: if the order of the examples in the text were reversed, the resulting discourse would be decidedly odd. If markers, then, are not interchangeable, it is likely that they are not devoid of semantic content, either. Presumably, Gülich's basic problem is that she takes a referential semantics for granted, and, as markers obviously do not refer to anything, it is but a small step to conclude that they have no semantic content.

A later, and highly influential, model for the analysis of markers is the so-called Argumentation Theory (which I will henceforth refer to as AT) of Oswald Ducrot and his collaborators (e.g. Ducrot et al., 1980; Anscombre and Ducrot, 1983). AT incorporates a non-referential, purely instructional theory of semantics, in which connectives are seen as instructional markers, of a basically argumentational nature, argumentation being conceived of in terms of discourse dynamics, in the sense that the meaning of a given utterance is a function of the set of utterances that may felicitously follow it in a coherent piece of discourse. The content of argumentational connectives and operators is defined by variables, rather than constants, and may be represented by generalized semantic schemata such as (48). The schemata are generalized in the sense that they may undergo certain changes, depending on the context of use. As, I mentioned earlier, AT's approach to lexical semantics is thus a largely minimalist one.

(48) Semantic schema of the conjunction mais

$p$ mais $q$, where $p \rightarrow r, q \rightarrow$ non-r, $(p$ mais $q) \rightarrow$ non-r

Here, $\mathrm{p}$ and $\mathrm{q}$ represent the propositions being connected; $r$ and non-r represent possible conclusions to be drawn; and $\rightarrow$ ('fish-hook') indicates that the first proposition is to be understood as an argument in favor of the second. What the schema then shows is that, in the compound utterance $p$ mais $q, \mathrm{q}$ is to be understood as the stronger argument, which turns the whole into an argument for the conclusion non-r.

In the more recent formulations of AT (now called 'Radical Argumentativism', cf. Anscombre and Ducrot, 1989; Nølke, 1992), the relation between the argumentational aim of the utterance and the intended conclusion is specified by so-called 'topoï' (Ducrot, 1983: 13). These are general principles or norms of a graded nature, which make the conclusion accessible.

Thus, in (49), the relevant topoï underlying the utterance of the two coordinate sentences might, depending on the context, be something like 'The more intelligent someone is, the more reason there is to hire him', and 'The more lazy someone is, the more reason there is not to hire him'. 
The implied conclusion $r$ of the argument $p$ would then be something like 'So let's hire him', and the implied conclusion non-r of the argument $q$ (and hence of the utterance as a whole) would be 'So let's not hire him'. With respect to discourse markers, the claim is then that the presence of argumentational items such as mais in an utterance functions to restrict the set of possible subsequent utterances in specific ways.

Given the aims of this paper, it does not seem appropriate to go into much greater detail concerning AT. Suffice it to say that, while the theory certainly incorporates a number of important insights and has led to very fine-grained analyses of certain linguistic items, it is also open to criticism on various counts. In this context, the most important point is that the allegedly inherent argumentational properties that AT ascribes to utterances containing markers are, in fact, not invariant and context-independent. Anscombre and Ducrot (1983: 30) do note that, of course, in actual discourse practically any utterance may follow any other, and go on to appeal to a notion of an 'ideal discourse', which is all they are concerned to describe. Clearly, this is an extension to pragmatics of Chomsky's notion of 'competence', and like the latter it has the potential for becoming an escape hatch whenever counterexamples are brought to the researcher's attention. It seems to me, however, that the theory simply makes the wrong predictions in a number of cases, for which 1 refer the reader to Hansen (1998: Ch. 2).

Secondly, there is the empirical question of whether all discourse markers are necessarily argumentational in nature. I do not know that AT explicitly makes such a claim, but descriptive studies within the framework have seemed to proceed on the tacit assumption that this is indeed the case. Now, as far as at least some of the markers treated in my work are concerned, I find it exceedingly difficult to ascribe an inherent argumentational function to them. For instance, in what way does ben in (50) constrain the argumentational force of its host utterance?

(50) ... et après vous pourrez,, grâce à vos souvenirs à vous mettre des notes en disant ben à ce moment-là ils ont souri ou ils ont eu l'air ennuyé ou ça a eu l'air de leur casser les pieds...

Other of 'my' particles, such as eh bien, alors and donc, have been treated as wholly or at least primarily argumentational (e.g. Sirdar-Iskandar, 1980; Zénone, 1981, 1982; Gerecht, 1987; Roulet et al., 1987; Rødbro-Pedersen, 1992; Ferrari and Rossari, 1994), but, as I argue in Hansen (1996, 1997, 1998), they are perhaps more felicitously analyzed in other terms, the more so as an argumentational function is not apparent in many uses of these items.

The so-called Geneva School, represented most prominently by Eddy Roulet and Jacques Moeschler (cf. Roulet et al., 1987; Moeschler, 1985, 1994, for comprehensive presentations), combines the AT approach with what is in principle supposed to be a generative theory of discourse structure, and proposes a model in which markers, besides indicating argumentational relations, may also function as indicators of hierarchical structure in discourse. However, in Hansen (1998: Ch. 7), 
I argue strongly against the idea that discourse structure is the result of the application of a set of internalized rules of a specifically linguistic nature. While speakers clearly orient to extralinguistic goals and to topical coherence, it is much less obvious that they orient to the structure of the discourse as such. It seems to me that whatever structure we may observe post hoc in actual discourse is more usefully seen as derivative of extralinguistic pragmatic factors such as the already mentioned topic coherence, local and global transactional and interactional goals, politeness considerations (for instance in the case of so-called pre-sequences, cf. Levinson, 1983: 345ff.), and the like. In Hansen (1998: Ch. 7), I try to show that discourse structure, as such, is 'emergent', rather than a priori. It is true, as the ethnomethodological literature amply demonstrates (e.g. Heritage, 1984), that all competent interactants have developed motivated and methodical ways of coping with interactional contingencies, but that does not mean that they simply implement preexisting knowledge in the production and interpretation of discourse. Members' actions can both modify existing knowledge and create new knowledge, and cognition and praxis cannot, therefore, be easily separated in the domain of social interaction.

Finally, in the work of Diane Blakemore (1987), which is situated within Relevance Theory (Sperber and Wilson, 1986), a handful of English connectives such as after all, moreover and but are analyzed as so-called 'semantic constraints on Relevance', i.e. as functioning as "constraints on the inferential computations the hearer performs in order to assess the impact of [the] proposition [on his representation of the world, M.-B.M.H.]" (Blakemore, 1987: 18). The interest of having the language provide such constraints lies in the definition of Relevance which informs her work:

" $[\mathrm{A}]$ ccording to the Principle of Relevance the hearer is entitled to interpret every utterance in the smallest and most accessible context that manifestly yields contextual effects. This means that if the speaker wishes to constrain the interpretation that the hearer recovers, then she must constrain her choice of context by making the necessary assumptions immediately accessible, thus ensuring their selection at minimal processing cost." (Blakemore, 1987: 76-77)

Blakemore (1992: 137-142) offers a tripartite classification of discourse connectives, according to the way their host utterance is intended to achieve relevance. First, we have connectives which introduce contextual implications, e.g. so, which indicates that its host utterance "must be interpreted as a conclusion" (Blakemore, 1992: 139). Secondly, we have connectives which are concerned with the strengthening of such implications, e.g. after all, which is said to indicate that "the proposition it introduces is evidence for an assumption which has just been made accessible" (Blakemore, 1992: 140). Thirdly, there are connectives which introduce denials, e.g. however, which marks its host utterance as "inconsistent with a proposition that the speaker assumes the hearer has derived as a contextual implication from the first utterance" (Blakemore, 1992: 141). 'This is strongly reminiscent of AT's distinction between arguments, counter-arguments, and conclusions, and although I believe that this sort of analysis may be perfectly adequate for certain items, I cannot help but feel - and I believe this to be supported by my data - that the classification represents an impoverished view of what markers may achieve in 
discourse, inasmuch as the three categories mentioned are all concerned with what one might call 'quasi-logical' relations between utterances.

Although I do, to some extent, make reference to relevance-theoretical notions in my descriptions of specific French markers, I consider their range of possible meanings and functions to be a good deal broader than Blakemore acknowledges, and I will now use the item bon as a case in point.

\section{Bon ${ }^{12}$}

The discourse marker bon is, of course, derived from the corresponding adjective. There is, however, little doubt that the two, although clearly related, are synchronically distinct items, both morphologically, syntactically, ${ }^{13}$ and semantically. But because of their semantic relatedness, I will argue that the adjectival and the adverbial (i.e. discourse marking) bon can be represented as nodes in a single heterosemous network, with certain uses being on the borderline between adjective and discourse marker, and thus providing a bridge from one to the other. ${ }^{14}$

While, in very general terms, the adjective bon indicates a positive evaluation of some phenomenon, one might say that the function of the discourse marker is to mark acceptance in a rather wide sense of the word. My examples of the latter fall into two major categories. In the first, which I will call the 'interjective' use, the morpheme occurs turn-initially, and the speaker communicates that she accepts a given discourse phenomenon, which may be the content of an utterance, a speech act, or in some cases, an extralinguistic situation, and which may be seen as somehow undesirable:

(51) A. est-ce que:

B. alors attendez si vous permettez René/ si vous permettez Henri Amouroux euh: j'aimerais que Claude Estier d'abord réponde et ensuite vous interviendrez

A. bon, d'accord, très bien (VS1: 4)

In this use, the function of bon is largely 'interactional', that is to say that the particle is used as part of the process of negotiating the social roles of speaker and hearer. The hearer is instructed, on the one hand, to identify the phenomenon in question, and, on the other hand, to incorporate the fact that the speaker accepts this phenomenon, and any consequences thereof, into her mental representation of the interaction at hand.

For a more detailed consideration of this marker, see Hansen (1998: Ch. 10).

1.3 The adjective may be inflected for gender and number, and functions syntactically either as a noun modifier or as the main predicate of a clause. The discourse marker, on the other hand, is invariable, and functions adverbially.

14 The substantival bon, as in $1 /$ y a du bon dans cet ouvrage or $/ 1$ m'a donne un bon d'essence, can be straightforwardly incorporated into the same network, as extensions from the adjectival use, although I will not go into that here. 
In the second type of uses, which I call the discourse marking use 'proper', bon occurs inside a turn, and the speaker is asking her interlocutor to accept some locally undesirable discourse phenomenon, because, she implies, this phenomenon will turn out to be appropriate for the interaction on a more global level:

... alors au niveau d'Amarna actuellement y a plus rien bon avec les b/les/ je crois qu'y a des circuits qui y vont mais nou:s bon on n'y est pas allés ... (VE: 57)

Here, the particle typically has a more 'cognitive' function, pertaining to the process of comprehending the discourse. Again, the hearer is instructed to identify the relevant phenomenon, but this time he is being asked to accept its existence, and simply proceed with his construction of a mental representation of the discourse despite the apparent unacceptability of what is currently taking place.

Now, the term 'undesirable discourse phenomenon' of course calls for explication. A phenomenon may be undesirable on different levels: the interactional, the textual, or the propositional content level.

On the interactional level (which is relevant primarily for interjective bon), an action or an element of the discourse may constitute a threat to the interlocutor's 'face' (cf. Brown and Levinson, 1987). This is the case in (51), in which speaker B interrupts the question that $\mathrm{A}$ is about to ask. With bon, $\mathrm{A}$ expresses his acceptance of this face-threatening interruption.

Alternatively, the speaker may feel that a preceding action, utterance, or exchange, although admissible in terms of the on-going interaction, was irrelevant, and wish to change the direction of the discourse:

(53) A. ah elle escrit elle écrit sur Giscard et sur Mitterrand si je ne me trompe \& c'est ça bon \&\&

B. \& oui \&\& ça fait une grosse béquille quand même hein

C. sur Giscard et sur Chirac

A. oui elle a la maîtrise

C. et sur Mitterrand

A. oui

C. ben elle écrit elle était journaliste elle le fait dans l'actualité

A. oui

C. hein

A. non mais

C. vous avez l'air de lui reprocher

A. mais moi je reproche rien

C. vous voulez qu'elle pa qu'elle fasse une biographie de Barre préventive?

A. bon alors on peut parler on peut parler du contenu? (MP: 3-4)

In this extract, the speaker is using bon in an attempt to terminate the on-going exchange, whose content he considers less than relevant under the circumstances. The attempted topic change betrays an interactional conflict between the inter- 
rupted' speaker's desire to continue the exchange and an opposite desire on the part of the 'interrupting' speaker to close the exchange. A speaker can use bon to mitigate a move of this kind, by showing that, given the nature of the conversation, she accepts the interlocutor's right to say whatever he was saying.

On the textual level (which pertains primarily to turn-internal, i.e. discourse-marking, bon), there may be an apparent break in coherence. Unplanned speech contains a great many utterances in which thematic continuity may seem to be in peril because speakers abruptly shift to new topics, return to earlier ones, or continue their discourse in ways which require that the hearer go through a series of inferential steps in order to understand. Such phenomena may impair the construction of a coherent mental representation of the discourse:

(53) A. dans le musée déjà déjà elle nous a donné des dates alors déjà c'était \& compliqué,

B. \& oui

A. mais elle nous a dit bon ben maintenant $\&$

B. \& oui

A. après on va revoir tout ça au fur et à mesurc, puis après l'après-midi ils nous ont emmenés à Saqqarah?

B. oui

A. enfin bon ils disent Saqqarah le plateau de Guiseh mais je sais qu'y a des noms qu'on dit pas tout à fait pareil qu'eux, eux ils disent Guiseh (VE: 17-18)

From relating the events of her first day in Egypt, speaker A abruptly switches to a new (although of course not unrelated) topic, namely that of the pronunciation of Egyptian place names. Bon may be said to signal to the hearer that the speaker is aware that this represents a digression which cannot straightforwardly be integrated into the mental representation under construction. The hearer will therefore have to establish a new mental model, which, however, will overlap with the current one through the presence of the place name 'Saqqarah' and the knowledge associated with it.

Alternatively, on the textual level, there may be doubt about what is to be admitted into the mental representation under construction, either because the participants disagree as to the nature of the facts being related, or because speakers may at times appear to contradict themselves, which ipso facto makes the integration of the incoming information into an existing mental representation difficult:

(55) A. moi je ferais trop confiance aux gens,, elle elle est peut-être trop méfiante, mais elle A raison, tu vois? ce serait un peu le genre/ (h) tu te rappelles quand on a été prendre le livre, Isabelle?

B. QUEL livre?

A. euh:: on est rentrées à la fac et puis y avait une:/ y avait des livres sur les/ sur les étagères

B. oui 

A. tu te souviens?
B. oui
A. et puis/ le gars i/ je lui ai dit mais je vous l'achèterai demain, et il a dit non moi je vous fais pas confiance, tu te souviens?
B. oui
A. eh ben/ c'est l'attitude de Nadia
B. ouais mais lui c'est différent puisque lui il était un/ il parlait en tant que vendeur

A. (h) oui mais Nadia, elle, bon elle/ bon elle te parle pas en tant que:, que vendeuse mais Elle, est-ce/ quand eh quelqu'un qui est à la maison, il rentre CHEZ elle c'est-à-dire, chez/ dans quelque chose où elle est habituée, où elle est naturelle, tu vois

B. $\mathrm{mm}$

A. donc Nadia, si elle l'adopte, je vais t'expliquer quand elle adopte quelqu'un elle l'adopte complEtement (C.T: 11-12)

Here, speaker A is conceding a point to her interlocutor, the concession being marked formally by mais. We can analyze bon as marking her acknowledgement that, without the correction implied by the hearer's contribution, her own previous utterance might have led to inaccurate conclusions. At the same time, bon signals that the original line of argument is still essentially valid and will not be abandoned.

Finally, on the level of propositional content, an utterance (or element of one) may be undesirable because its meaning is unclear, or it is not informative enough under the circumstances:

(56) A. ... non mais c'est parce que je parle avec toi

B. ouais

A. tu vois, (h) mais euh: comme/ que si par exemple ta mère m'avait au bout du fil

B. oui

A. bon, j'appelle, c'est elle qui décroche, eh ben elle aurait l'impression que je suis une petite fille (CT: 7)

In this example, A's initial formulation of the conditional antecedent (si par exemple ta mère m'avait au bout du fil) is slightly ambiguous, inasmuch as she does not specify who has called whom in the hypothetical situation. In the context, however, it is important that the caller be herself, and she therefore adds a clarification, marked by bon.

On all three levels, then, speakers may use bon as a means of negotiating a development of the discourse which may be satisfactory to all those concerned.

Although the discourse marking use of bon is subtly different from the interjective use, and although both are distinct from its use as an adjective, it nevertheless seems legitimate to analyze bon as 'heterosemous', i.e. as cross-categorically polysemous, its various admissible uses constituting a radial category (cf. Lakoff, 1987: 65), i.e. a category which is not defined by necessary and sufficient conditions for member- 
ship, but which is structured in terms of central and less central members, and which may thus be extended on an item-by-item basis, should circumstances make this relevant. As already mentioned, extensions from the core of such a category are not necessarily predictable, but they are cognitively motivated.

In the case of bon, the adjectival use would then form the core of the category, as the other uses, in which acceptance is either signalled or requested, can be argued to be extensions of the basic adjectival meaning of approval. Thus, when bon functions adverbially, the 'positive evaluation' meaning has been partially bleached, with only the notion of mere acceptance (which may be given more or less enthousiastically) remaining.

Interjective bon, whose function is close, although not identical, to that of the clausal expression c'est bon (and which is likely to have been derived from the latter), would be fairly close to the core, with some examples being on the borderline between adjectival and truly adverbial uses: that is, in a few cases it seems at least marginally acceptable to insert c'est in front of bon, although in most instances such an elliptical interpretation would not be felicitous. Moreover, here it is the speaker herself who is accepting some contextually determined phenomenon (one which is relevant primarily on the interactional level of the discourse), just as it is she who is evaluating some entity or situation positively when the adjective is used.

The discourse marking use 'proper', on the other hand, would be a more peripheral extension. Its meaning has moved much further from that of the clausal expression c'est bon, and it is no longer the speaker, but the hearer who is meant to give his acceptance of some phenomenon in the context (typically one which pertains to the contents of what is said).

As examples (51) and (53) show, the use of interjective (i.e. interactional) bon strongly tends to mark the end of the conversational sub-sequence to which it belongs. This is not at all the case for discourse-marking bon. That this should be so follows straightforwardly from the different ways in which they function, in so far as an apparent break in coherence or lack of clarity can only be resolved if the hearer allows the speaker to pursue the sequence, whereas minor interactional trouble may best be dealt with by a token acknowledgement by the 'offended' party followed by the initiation of a new sub-sequence. In other words, different uses of the morpheme have different consequences for the ensuing discourse. $\Lambda \mathrm{n}$ polysemy analysis, which recognizes bon may have more than one conventional meaning variant offers a better account of this fact than would a minimalist analysis describing the particle as having an abstract core meaning of acceptance to be further specified by the context.

\section{Conclusion}

I have argued, in this paper, for the combination of a globally instructional theory of semantics with an approach to meaning variation which allows for the existence of motivated lexical polysemy.

Although such an approach, which of course belongs firmly to the functional-cognitive paragdigm in linguistics, is meant to be relevant to research on other parts of speech as well, I have taken my point of departure in the study of discourse markers. 
these items being of a non-conceptual, and highly multifunctional nature, indicating in various ways how, and to what extent, their host units can be understood to make sense with respect to a mental representation of the discourse-so-far.

My examples have been drawn exclusively from French and English, but I believe that the approach sketched here may be of wider crosslinguistic applicability. Clearly, however, the theory needs to be further refined, and its limits as well as its full potential need to be tested on a more ample range of material.

\section{References}

Anscombre, Jean-Claude and Oswald Ducrot, 1983. L'argumentation dans la langue. Brussels: Mardaga. Anscombre, Jean-Claude and Oswald Ducrot, 1989. Argumentativity and informativity. In: Michel Meyer (ed.), From metaphysics to rhetoric, 71-87. Dordrecht: Kluwer.

Blakemore, Diane, 1987. Semantic constraints on relevance. Oxford: Blackwell.

Blakemore, Diane, 1992. Understanding utterances. Oxford: Blackwell.

Brown, Penelope and Stephen C. Levinson, 1987. Politeness. Some universal in language usage. Cambridge: Cambridge University Press.

Burge, Tyler, 1989. Wherein is meaning social? In: Alexander George (ed.), Reflections on Chomsky, 175-191. Oxford: Blackwell.

Carston, Robyn, 1993. Conjunction, explanation and relevance. Lingua 90, 27-48.

Coates, Jennifer, 1983. The semantics of the modal auxiliaries. London: Croom Helm.

Cohen, L. Jonathan, 1971. Some remarks on Grice's views about the logical particles of natural language. In: Yehoshua Bar-Hillel (ed.), Pragmatics of natural languages, 50-68. Dordrecht: Reidel.

Ducrot, Oswald, Danièle Bourcier, Sylvie Bruxelles et al., 1980. Les mots du discours. Paris: Editions de Minuit.

Ferrari, Angela and Corinne Rossari, 1994. De donc à dunque et quindi: Les connexions par raisonnement inférentiel. Cahiers de linguistique française 15, 7-49.

Foolen, Ad, 1993. De betekenis van partikels. Ph.D. dissertation, University of Nijmegen.

Gerecht, Marie-Jeanne, 1987. Alors: opérateur temporel, connecteur argumentatif et marqueur de discours. Cahiers de linguistique française $8,69-79$.

Grice, H. Paul, 1975. Logic and conversation. In: Peter Cole and Jerry L. Morgan (eds.), Syntax and semantics, Vol. 3, 41-58. New York: Academic Press.

Gülich, Elisabeth, 1970. Makrosyntax der Gliederungssignale im gesprochenen Französisch. Munich: Fink.

Hansen, Maj-Britt Mosegaard, 1995a. Marqueurs métadiscursifs en français parlé: l'exemple de bon et de ben. Le français moderne 63(1), 20-41.

Hansen, Maj-Britt Mosegaard, 1995b. Puis in spoken French: From time adjunct to additive conjunct? Journal of French language studies 5(1), 31-56.

Hansen, Maj-Britt Mosegaard, 1996. Eh bien: Marker of comparison and contrast. In: Elisabeth Engberg-Pedersen, Michael Fortescue, Peter Harder, Lars Heltoft and Lisbeth Falster Jakobsen (eds.), Content, expression and structure. Studies in Danish Functional Grammar, 315-342.

Hansen, Maj-Britt Mosegaard, 1997. Alors and donc in spoken French: A reanalysis. Journal of Pragmatics 28(2), 153-187.

Hansen, Maj-Britt Mosegaard, 1998. The function of discourse particles. Pragmatics and Beyond New Series 53. Amsterdam: Benjamins.

Harder, Peter, 1991. Linguistic meaning: Cognition, interaction and the real world. Nordic Journal of Linguistics 14, 119-140.

Harder, Peter, 1996. Functional semantics. A theory of meaning, structure and tense in English. Berlin: de Gruyter.

Harder, Peter and Ole Togeby, 1993. Pragmatics, cognitive science and connectionism. Journal of Pragmatics 20, 467-492. 
Heim, Irene R, 1982. The semantics of definite and indefinite noun phrases. Ph.D. dissertation, University of Massachusetts, Amherst.

Heritage, John, 1984. Garfinkel and ethnomethodology. Cambridge: Cambridge University Press.

Hopper, Paul J. and Elizabeth Traugott, 1993. Grammaticalization. Cambridge: Cambridge University Press.

Johnson-Laird, Philip N., 1977. Procedural semantics. Cognition 5, 189-214.

Johnson-Laird, Philip N., 1983. Mental models. Cambridge, MA: Harvard University Press.

Kroon, Caroline, 1995. Discourse particles in Latin. Amsterdam: Gieben.

König, Ekkehard, 1991. The meaning of focus particles. London: Routledge.

Lakoff, George, 1987. Women, fire, and dangerous things. Chicago, IL: University of Chicago Press.

Lamiroy, Béatrice and Pierre Swiggers, 1991. The status of imperatives as discourse signals. In: Suzanne Fleischman and Linda R. Waugh (eds.), Discourse pragmatics and the verb: The evidence from Romance, 120-146. London: Routledge.

Levinson, Stephen C., 1983. Pragmatics. Cambridge: Cambridge University Press.

Lichtenberk, Frantisek, 1991. Semantic change and heterosemy in grammaticalization. Language 67(3), 475-509.

Lyons, John, 1977. Semantics, Vol. 2. Cambridge: Cambridge University Press.

Moeschler, Jacques, 1985. Argumentation et conversation. Paris: Hatier-Crédif.

Moeschler, Jacques, 1994. Das Genfer Modell der Gesprächsanalyse. In: Gerd Fritz and Franz Hundsnurscher (eds.), Handbuch der Dialoganalyse, 69-94. Tübingen: Niemeyer.

Moore, Terence and Christine Carling, 1982. Understanding language. London: Macmillan.

Nølke, Henning, 1992. Semantic constraints on argumentation: From polyphonic micro-structure to argumentative macro-structure. In: Frans H. van Eemeren, Rob Grootendorst, J. Anthony Blair and Charles A. Willard (eds.), Argumentation illuminated, 189-200. Amsterdam: SICSAT.

Nolke. Henning, 1994. Linguistique modulaire: De la forme au sens. Aarhus: Aarhus Business School.

Posner, Roland, 1979. Bedeutungsmaximalismus und Bedeutungsminimalismus in der Beschreibung von Satzverknüpfern. In: Harald Weydt (ed.), Die Partikeln der deutschen Sprache, 378-394. Berlin: de Gruyter.

Posner, Roland, 1980. Semantics and pragmatics of sentence connectives in natural language. In: J.R. Searle, F. Kiefer and M. Bierwisch (eds.), Speech act theory and pragmatics, 169-203. Dordrecht: Reidel.

Rosch, Eleanor, 1977. Human categorization. In: Neil Warren (ed.), Studies in cross-cultural psychology, Vol. 1, 1-49. London: Academic Press.

Roulet, Eddy, 1991. Vers une approche modulaire de l'analyse du discours. Cahiers de linguistique française 12, 53-81.

Roulet, Eddy, Antoine Auchlin, Jacques Moeschler, Christian Rubattel and Marianne Schelling, 1987. L'articulation du discours en français contemporain. Second edition. Bern: Lang.

Rødbro-Pedersen, Jane, 1992. En logisk-semantisk, semantisk-pragmatisk beskrivelse af $e$ hien. M.A. thesis, University of Copenhagen.

Sirdar-Iskandar, Christine, 1980. Eh bien! Le Russe lui a donné cent francs. In: Oswald Ducrot, Danièle Bourcier, Sylvie Bruxelles et al., Les mots du discours, 161-191. Paris: Editions de Minuit.

Sperber, Dan and Deirdre Wilson, 1986. Relevance. Communication and cognition. Oxford: Blackwell. Sweetser, Eve, 1990. From etymology to pragmatics. Cambridge: Cambridge University Press.

Taylor, John R., 1989. Linguistic categorization. Oxford: Clarendon.

Traugott, Elizabeth Closs, 1990. From less to more situated in language: The unidirectionality of semantic change. In: Sylvia Adamson, Vivien Law, Nigel Vincent and Susan Wright (eds.), Papers from the 5th international conference on English historical linguistics, 497-517. Amsterdam: Benjamins.

Traugott, Elizabeth Closs, 1997. Structural scope expansion and grammaticalization. Paper presented to the Linguistic Circle of Copenhagen, 4 March.

Winters, Margaret E., 1990. Toward a theory of syntactic prototypes. In: Savas L. Tsohatzidis (ed.), Meanings and prototypes, 285-306. London: Routledge.

Wittgenstein, Ludwig, 1971. Filosofiske undersøgelser. Copenhagen: Munksgaard. (Translation of: Wittgenstein, Ludwig, 1958. Philosophical investigations. Oxford: Blackwell.) 
Zénone, Anna, 1981. Marqueurs de consécution: Le cas de donc. Cahiers de linguistique française 2, $113-139$.

Zénone, Anna, 1982. La consécution sans contradiction: Donc, par conséquent, alors, ainsi, aussi (première partie). Cahiers de linguistqiue française $4,107-141$. 